\title{
sciendo
}

\section{Interconfessional (Mixed) Marriage: The Theological Dimension of the "Person" and Pastoral Care in the History of the Holy and Great Council of Crete and Related Documents}

\author{
Alexandru-Marius Crișan
}

In the last century, under the influence of the theological personalism (theology of the Person), the Orthodox Church felt the need of a universal and uniform approach to different pastoral questions. Among those we find also the question of interconfessional (mixed) marriage. This question was approached during the preparation of the Holy and Great Council of Crete. In 2016 the Great Council of the Orthodox Church, finally convened, specified and confessed that inter-confessional marriages are forbidden according to the traditional canon-law (akriveia), but the salvation of the person must be kept in mind and permission could be given in the spirit of pastoral discernment (oikonomia). The history of the Council shows the struggle for finding a balance between canon law and pastoral care, regarding many pastoral issues nowadays, including inter-confessional marriage.

Keywords: Inter-confessional, mixed marriages, Holy and Great Council, PanOrthodox, personalism, person, pastoral care.

\section{Introduction}

Many weddings are performed over the entire Christian world, many of which are inter-confessional or even inter-religious mixed marriages. This applies also to the Orthodox Church which not only counts a strong and numerous diaspora but also, on account of political and social conditions both old and new, has a considerable non-orthodox presence in territories traditionally known as Orthodox. This is the case in Western Ukraine and Transylvania, both which have a notable and historic Catholic or Protestant presence. One could also mention the Former Yugoslav Republic of Macedonia with its fast-increasing Muslim population. Let me also note the current possibility of studying, working or traveling abroad. All these actual conditions increase the probability of mixed marriages for both the European and non-European Orthodox population. Even if there were different local approaches to the question of mixed marriages, the Orthodox Church

\footnotetext{
${ }^{*}$ Dr. Alexandru-Marius Crișan, Research Fellow, Institute for Ecumenical Research of Lucian Blaga University of Sibiu. Address: Mitropoliei 30, 550179, Sibiu, RO. E-mail: alexandru13marius@gmail.com.
} 
has felt the need for a modern and uniform approach and pastoral care for its spiritual children who have contracted such a marriage. For this study it shall be taken into consideration the most noteworthy pan-orthodox event from the recent history of the Orthodox Church: The so called Pan-Orthodox Council of Crete held in June 2016 and its preparation ${ }^{1}$. This article will try to analyze the pastoral and personalist approach of those involved in the preparation of the documents of this Council and, naturally, it will examine the final form of the documents approved in Crete two years ago.

\section{The theology of the Person}

Theological personalism regards a certain way of understanding God. For personalist theology ${ }^{2}$, God's ultimate identity resides not in His Trinitarian nature but in being Person. God is Trinity is just descriptive but is not an ultimate and ontological identity because God can't be just a relational substance; rather $\mathrm{He}$ is a Person(s) in which is found the very concrete identity of God. In the meantime, personalist theologians talk about the characteristic of the Person to incorporate and to be incorporated without the Person losing His identity. There is a perfect reciprocity between the Person who incorporates and the ones who are incorporated. This incorporation ${ }^{3}$ of many persons in one person is the way of explaining the unity of the nature (so unity is defined in a Person not substance $)^{4}$. This happens at all theological levels. For the Trinitarian theology, this is the fundament of the monotheistic aspect of Christianity.

\footnotetext{
The official name of this Council is The Holy and Great Council of the Orthodox Church, commonly known also as The Pan-Orthodox Council.

2 Some of the most representative authors for the personalist theology of $20^{\text {th }}$ century are: Emile Mounier, Maurice Nedoncelle, Jacques Maritain, Nicolai Lossky, Christos Yannaras, Nikolai Afanasiev, Ioannis Zizioulas.

3 For the incorporation aspect of the personalist theology, especially regarding the Christological aspect see: Emil Mersch, Le Corps mystique du Christ. Etudes de théologie historique, Louvain, Museum Lessianum, 1933; Ioannis Zizioulas, Eucharist, Bishop, Church, Brookline - Massachusetts, Holy Cross Orthodox Press 2001, p. 54-55; Andrew Perriman, "The corporate Christ. Re-assessing the Jewish background”, in: Tyndale Bulletin 50 (2/1999), p. 239-263; this aspect is taken into consideration by the Holy and Great Council of Crete, especially in the document regarding the The Mission of the Orthodox Church in Today's World, but also the Encyclical and (relevant for this study) in the document regarding the Sacrament of Marriage and its Impediments as we shall see further.

4 This actually is the philosophical-theological concept: The one and the many. For a philosophical and theological analysis of this concept in the light of the personalist theology see: Gareth Matthews, Marc Cohen, "The one and the many", in: The Review of Metaphysics 21 (1968), p. 630-655; I. Zizioulas, The One and the Many, Alhambra-California, Sebastian Press 2010; idem, Communion and the Otherness, London - New York, T\&T Clark International 2006, p. 163; idem, Lectures in Christian Dogmatics, London - New York, T\&T Clark International 2008, p. 52.
} 
We do confess actually in the Nicaean Creed that: "We believe in one God the Father". In God the Father are incorporated the other 2 Persons ontologically equal to the Father maintaining their identity unchanged. For Christology, Christ becomes the icon of the Father and he incorporates all the human persons like the old Adam. For the theological personalism it is important to emphasize the role of the concept of person at all levels in God. The concept of person is the theological explanation for defining God's most ontological identity and, in the meantime, the same concept is used to explain the unity and the multiplicity of God. So, for the personalist theologians, the concept we mentioned is to be found at the base of all theological levels. This is important to keep in mind before trying to identify the personalist approach of the preparations and documents of the Holy and Great Council of Crete.

Modern Orthodox theology in the last century courageously developed a theology of the human person. It is to be considered that the use of the expression human person in the Holy and Great Council documents is a victory of the personalist theology. Our communion with God in his Personhood allows theological thinking to approach human personhood as sacramentally incorporated in Christ's Person. This theological system becomes a source for the human person's dignity and for human social rights. Human is no longer just an image of something much greater than him (which could actually be considered as referring to the past) but someone in a present and active incorporation in relation to Christ. If the unity of Trinity is ontologically founded on the Person of Father, the unity of the universal Church is founded not on common ideology or image but on and in a Person. The freedom and the dignity of the human person are an active reflection of the freedom and dignity of the Trinitarian Persons. This leads to the fact that ultimate communion between humans is in their personhood, according to the personalist theology. The One (Christ) who incorporates the many human persons gives them a strong unity and diversity at the same time. Being different remains important but can't affect ontologically the being's unity because, in the Church, it is shared as a common personhood by being ecclesiastically incorporated in the Person of Christ. From here flows the importance of the Person. The Holy and Great Council of the Orthodox Church finds the source for a theology of the personal freedom and dignity in the corporate Christ.

\section{The question of Mixed Marriage in the Holy and Great Council of Crete history and related documents}

The sufferings of the last century contributed much in moving towards a specific kind of theology in the preparation for the Council, even if this path was followed involuntarily. Of course, today after almost one century 
of peace and welfare it is difficult to have our attention fixed on that which is necessary, but with the passing of time we pay more and more attention to rules even in theology. This happened also with the document concerning mixed marriage. Let us now see how the theme of marriage appeared and developed as a topic in preparations for the Holy Council and how the question of inter-confessional mixed marriage was approached.

Like the theology of the Person, the Great Council of Crete had its history marked by politically important events that led to huge tragedies in Europe and mostly in Eastern-European countries which traditionally appertain to the Orthodox Church. As we shall see, these tragic events had a huge influence on the theological and philosophical thinking of the middle $20^{\text {th }}$ century. Tragedies always make possible the return of one's attention to the very essential things. Definitely, the two world wars, the dictatorial systems and the displacing of population made possible also a rediscovery of a theology centered on that essential concept in Christianity, the Person.

Metropolitan Hilarion Alfeyev in his history of the Council initiates his analysis in the document about marriage by beginning in 1971 when, at the First Meeting of the Inter-Orthodox Commission, the participants discussed the impediments to marriage 5 . Here the title already has a negative and prohibitive form (impediments to something) but actually the roots of this document are to be found at the very first meeting of preparatory process of the Holy and Great Council, the Pan-Orthodox Congress of 1923. Two of the themes taken into consideration then were concerning marriage: "The priority of the sacrament of marriage and the sacrament of ordination" and "Remarriage of the widowed priests and deacons".

It is still important to observe that initially the question of the document about marriage appears in a positive and not prohibitive form. From the very first moment the question of marriage was taken into consideration so that some rules might be reconsidered and perhaps alleviated. A re-analysis of a question that serves only for re-confirmation and to re-affirm the strictness of a rule doesn't have, in the end, any sense. Obviously, at that time (1923) the Orthodox World found itself in the post-war era. The direct memory of the sufferings of the Great War was also a decisive factor in promoting a permissive view of the canons, which was actually based on the theology of the person. The centrality of the person led the participants of the council to bring into discussions the, until then, traditionally held rules and canons in order to facilitate good life conditions for everyone and to avoid

\footnotetext{
See: Hilarion Alfeyev, "Le saint et grand concile de l'Église Orthodoxe", in: Irénikon 84 (2-3/2011), p. 213.

6 See: Viorel Ioniță, Towards the Holy and Great Synod, Studia Ecumenica Friburghese 62, Fribourg, Friedrich-Reinhardt 2014, p. 7.
} 
conflicts. From the final document of the 1923 Pan-Orthodox Congress we can easily see the willingness of the Congress members to try to understand the spirit of the canon so they might enlarge the interpretation of the canon:

The appropriate practice established earlier and preserved up to the present for the welfare of the Church, may be changed for the same benefit of the Church as required by the hierarchs and believers as well. This is also understood from the Scriptures (see Cor. 9:5) and is compatible with the spirit of the Ancient Church (see the Canon 10 of Ancyra). The Conference decided, sometimes unanimously, sometimes by majority vote, the following:

1. To recognize that there is no dogmatic reason for a permanent anteriority between the mysteries of marriage and priesthood, and to consider that, in principle the marriage of the priest and deacons after ordination is allowed, with the exception of those who have taken the monastic vows.

2. The synods of the local churches have the right, with the approval of the local bishops, to allow the marriage of the priests and deacons who so petition.

3. This measure is reckoned valid from a canonical point of view, until the convocation of a Pan-Orthodox Synod, to which alone is reserved to invest this legislation with universal validity ${ }^{7}$.

The Canon mentioned is 10 of Ancyra which actually allowed only for ordained deacons to marry after ordination; meanwhile the text here enlarges this permission also to priests. Thus, the preparation of the Holy and Great Council regarding the marriage question began by trying to understand the Spirit of the canon and to go further in the light of personalist thought and theology.

Furthermore, the text gives a great power and freedom to the local bishop to act, offering a dispensation for the marriage of a deacon or a priest. Some may say that this freedom for the bishop is against Church canon law, however, this fact confirms a certain theology of the centrality of the bishop where the bishop is considered to be an Alter Christus and a base of unity for the diocese and an eschatological prophecy. Moreover, the bishop is the chief legislator of canon law for his diocese because he knows better than anyone else, which is the best pastoral measure to take for the benefit of the Church. As we see in the end of this phrase of the document the measure is valid only until the Convocation of the Holy Council.

The next important step regarding the question of marriage was made at the Third Pan-Orthodox Conference of Chambésy in 1968. Here it is easy to observe that the affirmative titles of the 1923 Orthodox Congress changed into

Ibidem, p. 108. 
a negative and prohibitive form: The priority of the Sacrament of Marriage and Remarriage of the widowed priests and deacons (both affirmative forms) became Impediments to marriage (a prohibitive form). This theme in its prohibitive form was entrusted to the Russian Church and to the Church of Greece for study and debate ${ }^{8}$. The conclusions of this study were taken into consideration by the First Meeting of the Preparatory Inter-Orthodox Commission (1971). During the Commission's debate there arose another question regarding marriage: that of mixed or inter-confessional marriage9. Even if the title of the theme was a restrictive one (Impediments), the proposals were very open with a special attention for pastoral care regarding the inter-confessional marriages:

a) The Russian Church accepts that the sanctification of marriage of Orthodox Christians with non-Orthodox Christians in an Orthodox church wedding can take place in the case where the non-Orthodox party recognizes the importance of the Orthodox Church blessing.

b) The Greek Church believes that it would be better to avoid mixed marriages, without discrimination between Churches and confessions, and admit them only if there are special reasons.

c) The Polish Church proposes that, in accordance with the spirit of ecumenism and on the basis of local inter-confessional relations, mixed marriages with all baptized be recognized as valid ${ }^{10}$.

The participants of the 1971 meeting had some very interesting positions even regarding inter-religious marriage between an orthodox and a nonChristian:

a) The Russian Church recognizes that such mixed marriages are strictly prohibited by the $72^{\text {nd }}$ Canon of the Trullan Council, but nevertheless believes that "The Church of God on earth persistently demands, in relation to the issue of mixed marriages of Orthodox Christians with non-Christians, a return to the Church practice of the first three centuries of Christianity" (time when the mixed marriages were allowed). In addition, "in the oldest canons there is no prohibition on this issue".

b) According to the opinion of the Church of Cyprus, "it is forbidden for a Christian to marry a non-Christian $\left(14^{\text {th }}\right.$ Rule of the Fourth Ecumenical Council)".

8 Liviu Stan, "A patra Conferință Panortodoxă”, in: Biserica Ortodoxă Română 86 (78/1968), p. 870.

9 See: Antonie Ploieșteanul, "Lucrările Comisiei Pregătitoare a Sfântului și Marelui Sinod al Bisericii Ortodoxe Române”, in: Biserica Ortodoxă Română 89 (7-8/1971), p. 785-786.

10 See : H. Alfeyev, "Le saint et grand concile", p. 214. 
c) The Greek Church believes that the Pre-Council meeting could allow and apply the oikonomia to the issue of marriage with the heterodox.

d) The Polish Church suggests "discussing the possibility of the blessing of one of those who enter into marriage even if one of them is an unbeliever".

e) The Czechoslovak Church cannot bless the marriage of an Orthodox Christian with a non-Christian (Jew, Muslim, etc. ${ }^{11}$.

Some may find these opinions scandalizing but still, they are perfectly canonical, orthodox and biblical as shown, especially in the Russian Church position which quotes the First Letter to the Corinthians and mentions that in the older canons there is no prohibition about the inter-confessional marriage. And we should not forget that canon law has two ways of application: the so called akriveia and the oikonomia.

The observation of metropolitan Hilayon Alfeyev made in his article about the history of the Council regarding the different proposals of the 1971 Commission here is pertinent. He writes that every Church expressed opinions linked with the pastoral problems found in its canonical territory. In this sense the Greek Church which operates in a mostly mono-confessional society could afford to have a very restrictive view of the canon's application but (akriveia) the Ecumenical Patriarchate, the Russian Church and also the Polish Orthodox Church because of pastoral motives had to have a very open approach to canon law which actually didn't affect the spirit of the canons which remains a source of guidance (oikonomia) ${ }^{12}$.

The next event where the problem of mixed marriages was discussed was during the Second Pre-Conciliar Pan-Orthodox Conference held in September 1982. Departing from the proposals made in 1971 which were already mentioned, the 1982 Conference finally adopted a precise text, even though for many of the participants it was too restrictive by comparison to the 1971 proposals. The mixed marriage issue remains the only canonical question taken into consideration in the final document presented to the Holy and Great Council; the recommendation to allow the widowed priests and deacons to remarry (which was actually the basis, the starting point of the document) was not even mentioned anymore. Regarding the issue of the mixed marriage, the 1982 text says the following:

Concerning mixed marriages contracted between Orthodox and non-Orthodox, on one hand, and between Orthodox and nonChristians, on the other hand:

11 See: Ibidem, p. 214

12 Ibidem, p. 214-215. 
1. Marriage between Orthodox and heterodox is forbidden according to canonical akriveia. Nevertheless, it can be performed by dispensation and love, on the condition that the children born of this marriage will be baptized and raised within the Orthodox Church. The local Orthodox Churches may take decisions concerning the use of the oikonomia in given cases and for particular pastoral needs.

2. Marriage between Orthodox and non-Christians is absolutely forbidden in accordance with canonical akriveia. Nevertheless, the local Orthodox Church can decide regarding such a marriage, and make use of oikonomia for the Orthodox partner, keeping in mind the particular pastoral needs ${ }^{13}$.

So, the 1982 text of the document adopted states on the one hand that, according to the canonical akriveia, an inter-confessional and interreligious marriage could not be blessed in the Orthodox Church; but on the other hand, offered freedom to the local Churches, especially to the bishop, to bless for pastoral care not only out of love for his flock in general but for the person particularly.

In this phase the document promoted a vision of a dual and bilateral application of the canon law. In the meantime, by mentioning the local Church, the authority of the bishops in synodic communion to be a source of the canon law was confirmed.

Compared to the 1971 proposals, the 1982 document shows greater rigor, as can be observed. However, during the debates there were voices that asked for continuing in the same line of openness to follow the spirit of the canon and not necessarily the letter. One of the most considerable interventions regarding mixed marriages and the already abandoned theme of a second marriage for ordained deacons and priests is the speech of Metropolitan Parthenius, the future Patriarch of Alexandria, Parthenius III:

(...) pourquoi sommes-nous venus ici ? Il me semble pourtant que dans une réunion de ce genre nous devons être en la situation à la fois de dire la vérité et de faire preuve d'amour, mais aussi d'audace, pour faire face à nos responsabilités envers la réalité humaine actuelle. Aujourd'hui nous chrétiens, sommes en minorité, demain nous ne représenterons plus que le $20 \%$ de l'humanité. Nous devons présenter à l'homme contemporain une Orthodoxie vivante et agissante. Nous discutons de nombreuses questions, nous les acceptons, nous y croyons, et cependant nous hésitons à

13 See: "Concerning the topic Impediments to marriage", in: V. Ioniță, Towards the Holy and Great Synod, p. 154-155. 
les proclamer haut et fort. (...) La question du mariage des prêtres après l'ordination, personne ne peut empêcher l'Eglise de l'étudier. Et même du point du vue théologique. Bien sûr qu'alors nous transgresserons les canons. Il existe une tradition, mais je ne crois pas qu'elle se base sur le dogme. (...) Et le mariage entre orthodoxes et non-orthodoxe, pourquoi ne pas le permettre également? Le mariage est une institution sacrée. Il se fond sur la liberté individuelle et sur l'amour. Or nous, Eglise Orthodoxe, célébrons un tel mariage en établisse de clauses. (...) Dès leur premier instant de vie commune, nous ne faisons donc que créer des problèmes aux nouveaux mariés et les diviser. Nous n'avons même pas la liberté de reconnaitre que la vie change et qu'elle rapproche les hommes, orthodoxes, catholique romains, athées et agnostiques ${ }^{14}$.

One needn't analyze closely his words because the metropolitan was very clear. We can see in this speech a person-centered approach. The human person's dignity is enough to rethink the canons or at least to reinterpret the canons.

The paragraphs adopted in 1982 meeting concerning the mixed (inter-confessional and interreligious) marriages were reanalyzed in 2016 at the Synaxis of the Primates of the Orthodox Churches and partially modified. This Synaxis actually modifies only the inter-religious marriage component banning the possibility of blessing such a marriage and restraining the possibility of expanding canonical oikonomia to the inter-confessional issue. This fact could be interpreted in two ways, both of which are in light of personalist theology as we shall see below. The new form is this:

14 Synodica, vol. VIII - IIe Conférence Panorthodoxe Préconciliaire Chambésy, 3-12 septembre 1982. Procès verbaux - Documents, Le Secretariat pour la preparation du Saint et Grande Concile de l'Eglise Orthodoxe (ed.), Genève, Les éditions du Centre Orthodoxe I994, p. 124-133; authors translation: "Why did we come here? It seems to me that in a reunion of this kind we must confess the truth and do so in love, but also have the audacity to face our responsibility regarding current human reality. We hide ourselves beside the general opinion, the believers one, but have to have courage - and that's our responsibility - to mention to the people our own opinion. Nowadays, we, the Christians, are a minority, tomorrow we shall be less than $20 \%$ of the world's population. We must present to contemporary man Orthodoxy living and active. We talk about so many questions, we accept them and we do believe them, but after, we hesitate to proclaim them publicly (...) regarding the question of matrimony of clerics after ordination no one can prevent the Church from studying it. Even from the theological point of view. Surely that in this way we shall transgress the canons. There is a tradition but I do not believe it is based on doctrine. (...) And the marriage between orthodox and non-orthodox, why can it not be allowed? Matrimony is a sacred institution. It is founded on individual freedom and on love. And we, the Orthodox Church, celebrate such a marriage and establish provisions. (...) From the very first moment of their common life we do nothing but create problems dividing the new spouses. We don't even have the freedom to admit that life is changing and that it draws men together, Orthodox, Roman-Catholics, atheists and agnostics". 
Concerning mixed marriages of Orthodox Christians with nonOrthodox Christians or non-Christians:

1. Marriage between Orthodox and non-Orthodox Christians is forbidden and is not blessed in the Church, according to canonical akriveia (Canon 72 of the Quinisext Ecumenical Council). However, such a marriage can be blessed by dispensation and out of love, on the condition that the children born of this marriage will be baptized and raised within the Orthodox Church.

2. Marriage between Orthodox and non-Christians is categorically forbidden in accordance with canonical akriveia ${ }^{15}$.

The Synaxis also made another important change: they chose to come back to the affirmative form of the title; the Impediments to marriage become in the new title The Sacrament of Marriage and Its Impediments ${ }^{16}$. I do consider this fact as a step forward even if in the title there is still the mention of prohibition, but it is given less prominence.

This was the form that was taken into consideration by the Holy and Great Council. Before the gathering of the Council, between January and June, there were 4 Churches which unfortunately withdrew from participating the Holy and Great Council. With them of course we have 4 reasons for not attending the Council. It is the Georgian Church's rationale that interests us because it is directly related with this form of the document.

Reading the communiquér of the local Holy Synod of the Georgian Church regarding the withdrawal from attending the Council, found on the official website of the Georgian Church, we can observe that such a decision was taken because of the document about Marriage. In the document the problem found by the Georgian Church is exactly that of too much clemency accorded to the inter-confessional marriages. Metropolitan Theodor (Tchuadze) of Akhaltsikhe and Tao-Klarjeti made a very rigid speech against the unique paragraph maintained in the preparatory text that mentioned the possibility of according clemency for inter-confessional marriages. He proposed the following for $5^{\text {th }}$ paragraph:

"Marriage between Orthodox and non-Orthodox Christians is forbidden and is not blessed in the Church, according to canonical

15 Preconciliar document The Sacrament of Marriage and Its Impediments on the official site of the Holy Council: https://www.holycouncil.org/-/preconciliar-marriage, viewed on $1^{\text {st }}$ February 2018.

16 See: Ibidem.

17 Decree of the Holy Synod of the Orthodox Church of Georgia made 25 May 2016. See the original Georgian: http://patriarchate.ge/geo/wminda-sinodis-sxdomis-oqmi-25/, viewed $2^{\text {nd }}$ February 2018; or the Romanian translation: http://basilica.ro/biserica-ortodoxa-a-georgiei-comunicat-privind-sfantul-si-marele-sinod/, viewed on $2^{\text {nd }}$ February 2018. 
akriveia (Canon 72 of the Quinisext Ecumenical Council). However, such a marriage can be blessed by dispensation and out of love, on the condition that the children born of this marriage will be baptized and raised within the Orthodox Church".

Should be modified in this form:

"Marriage between Orthodox and non-Orthodox Christians is forbidden and is not blessed in the Church, according to canonical akriveia (Canon 72 of the Quinisext Ecumenical Council)"18.

The metropolitan wanted the elimination of the second phrase, that is: However, such a marriage can be blessed by dispensation and out of love, on the condition that the children born of this marriage will be baptized and raised within the Orthodox Church because he believes it is contrary to the aforementioned $72^{\text {nd }}$ canon of the Trullan Council.

I would like to criticize the Georgian position from at least 2 points of view. The first one regards the very approach of Metropolitan Theodor to the canon itself. An Orthodox approach to a canon requires two ways of application akriveia and oikonomia. By taking away from the document on marriage the possibility of celebrating inter-confessional marriages even with the mention of special cases with a special blessing of the bishop, the Georgian Metropolitan wants a unilateral and, thus, incomplete approach to the $72^{\text {nd }}$ Canon of the Trullan Council. Therefore, the document of the Holy and Great Council would not have a canonical approach faithful to the traditional point of view. Yet, let us examine the invoked Canon itself to determine if it has two ways of application or not:

An orthodox man is not permitted to marry a heretical woman, nor an orthodox woman to be joined to a heretical man. But if anything of this kind appears to have been done by any [we require them] to consider the marriage null, and that the marriage be dissolved. (...). If any one shall transgress the things which we have decreed let him be cut off. But if any who up to this time are unbelievers and are not yet numbered in the flock of the orthodox have contracted lawful marriage between themselves, and if then, one choosing the right and coming to the light of truth and the other remaining still detained by the bond of error and not willing to behold with steady eye the divine rays, the unbelieving woman is pleased to cohabit with the believing man, or the unbelieving man with the believing woman, let them not be separated, according to the divine Apostle, for the un-

18 See: Ibidem. 
believing husband is sanctified by the wife, and the unbelieving wife by her husband ${ }^{19}$.

In the first part we do find the akriveia aspect, that is, the literal application of the canon but in the second one we find that some exceptions are to be accepted in special cases, showing that the oikonomia aspect is also present in canon. Using this canon to combat the application of a contemporary necessary clemency means going against the very nature of every canon and to a canonical approach in generally. Another aspect is that with a unilateral application of the canon the person disappears from the center of the Christian thinking and a rule takes his place.

This unilateral vision is a vision with which the Christian faith couldn't actually spread. I think it is universally accepted the role of inter/religious marriage in spreading the new Christian faith. What amazes us is that this proposal comes from a people and a Church which has no fewer than 2 million believers outside Georgia especially in Western Europe.

It is time now to see the final form of the document, the one approved by the Holy and Great Council of June 2016. In its final and current form, the document The Sacrament of Marriage and its Impediments is divided in two parts. The first one is a theological introduction about orthodox marriage containing 11 paragraphs wherein are described some theological aspects of major importance: the divine institution, the Christ-centric aspects and the holiness of marriage. The other 6 paragraphs from the second of the document refer to different impediments and possible oikonomia to them. Between the impediments and oikonomia, we also find the topic of mixed inter-confessional marriages.

In June 2016 the Holy and Great Council modified little of the previous version of the document (the Primates Meeting January 2016), the theological part is left practically untouched but the part concerning the mixed-marriages was once again modified, a sign that the Holy Council took into consideration the Georgian position. This modification better explains why in certain occasions mixed-marriages could be blessed by the Orthodox Church. The new form is stated in the fifth paragraph:

Concerning mixed marriages of Orthodox Christians with nonOrthodox Christians or non-Christians:

i. Marriage between Orthodox and non-Orthodox Christians is forbidden according to canonical akriveia (Canon 72 of the Quinisext Ecumenical Council).

19 See: The Oecumenical Councils: from Nicaea I to Nicaea II, Giuseppe Alberigo et al. (ed.), Corpus Christianorum Conciliorum Oecumenicorum Generaliumque Decreta, vol. 1, Brepols, Turnhout 2006, p. 276. 
ii. With the salvation of man as the goal, the possibility of the exercise of ecclesiastical oikonomia in relation to impediments to marriage must be considered by the Holy Synod of each autocephalous Orthodox Church according to the principles of the holy canons and in a spirit of pastoral discernment.

iii. Marriage between Orthodox and non-Christians is categorically forbidden in accordance with canonical akriveia ${ }^{20}$.

By specifically mentioning the $72^{\text {nd }}$ canon of Trullan, Marriage between Orthodox and non-Orthodox Christians is forbidden according to canonical akriveia (Canon 72 of the Quinisext Ecumenical Council) in a separate phrase, the Council Fathers showed that this Council is aware of the church canonlaw and is faithful to previous Church legislation. By mentioning canonical akriveia, the document opens itself to a full faithfulness not only in that specific canon but to the canonical approach itself as was previously discussed.

The second sentence from the previous version: However, such a marriage can be blessed by dispensation and out of love, on the condition that the children born of this marriage will be baptized and raised within the Orthodox Church, was transformed in a separated phrase (sub-paragraph) that better explains canonical oikonomia and then offers a person-centered point of view not merely a general rule. The mention of expressions like: the salvation of man as the goal or in a spirit of pastoral discernment helps in constructing a person-centered theology. With all these references and adding also the mention of oikonomia, the final document about marriage approved by the Great Council is totally orthodox and profoundly Christian.

The decision of allowing, in special cases, through oikonomia the blessing of mixed marriages is accompanied by the absence of any kind of recommendation or command regarding the children baptism in a certain Church as was contained in previous versions. I do consider this another decision sprung from the personalist thinking. It is not at all easy deciding where to baptize one's children when one is in an inter-confessional marriage. By not mentioning a need for the Orthodox spouse to impose his/her Church, the Council gave freedom to decide and to act and so, in a certain way, strengthens the unity of the young spouses, a unity that is also subject to many other trials and temptations.

No less important is the Local Synod which according to this document retains the authority of ministering special pastoral care in allowing these marriages to be performed in the Orthodox Church. This is a final evi-

20 Official Conciliar document The Sacrament of Marriage and Its Impediments on the official site of the Holy and Great Council: https://www.holycouncil.org/-/marriage, viewed on $2^{\text {nd }}$ February 2018. 
dence of the presence in document of the theology of the bishop's centrality in his diocese as a legislator who codifies the canon law.

Of course, we could ask ourselves if these impediments and economies do completely agree with the Council's theological introductory part of the chapter or with other documents.

Firstly, in the theological part of the document on marriage we can see a strong Christological aspect of the marriage connected directly to Alter Cristus, and so to the concept of the bishop. In the second and third paragraphs of first theological part of the document we can clearly see the Christological and episcopal related theologies:

The mystery of the indissoluble union between man and woman is an icon of the unity of Christ and the Church (Eph. 5.32). Thus, the Christocentric typology of the sacrament of marriage explains why a bishop or a presbyter blesses this sacred union with a special prayer. In his letter to Polycarp of Smyrna, Ignatius the God-Bearer stressed that those who enter into the communion of marriage must also have the bishop's approval, so that their marriage may be according to God, and not after their own desire. Let everything be to the glory of God $(\mathrm{V}, 2)$. Therefore, the sacredness of the God-established union and the lofty spiritual content of married life explain the affirmation: So that marriage should be honored among all, and the bed undefiled (Heb. 13.4) ${ }^{21}$.

So the canon (a rule), a non-personal issue, it is not above the person, being it the spouses or the bishop. The bishop in his quality of corporative personality of the diocese as Alter Cristus and Alter Apostolus has to interpret the canons with pastoral care for the benefit of the Church.

The permission given to the bishops in communion of the Local Autocephalous Synods to allow mixed marriages is consistent with the first chapter theology of the bishop.

Permission for mixed marriages between Christians is also a sign of a deeper communion beyond confessional borders, a communion in the personhood of Christ. The limitation of the clemency only for the inter-confessional marriages and not for the inter-religious mixed marriages strengthens the Christological aspect of the marriage but leaves us in the meantime with a lot of questions.

For example: Do we have to take as granted that this clemency could apply also for future priests?

The document mentions that marriage is the oldest institution received by Adam and Eve in the Paradise. Despite any kind of interpretation

Ibidem. 
of the first chapters of the book of Genesis, it is clear that there is a view of a corporate personality. All of humankind rooted in Adam and Eve receives the institution of marriage and because of this, marriage has a universal aspect. Drastically limiting any possibility of offering clemency for inter-religious marriages begs the following question:

Isn't there a communion into the personhood of Adam between all human kinds? Or wasn't the mission of first centuries of Christian era the most efficient thanks to inter-religious marriages as the First Letter to Corinthians does suggest? Do we prefer to have just the nostalgia of the first Christians but not their courage and openness? 